\title{
Correction to: Eculizumab: A Review in Neuromyelitis Optica Spectrum Disorder
}

\author{
James E. Frampton ${ }^{1}$
}

Published online: 21 April 2020

(c) Springer Nature 2020

\section{Correction to: Drugs \\ https://doi.org/10.1007/s40265-020-01297-w}

The article Eculizumab: A Review in Neuromyelitis Optica Spectrum Disorder, written by James E. Frampton, was originally published electronically in SpringerLink on 7 April 2020 without Open Access. After publication Alexion Pharmaceuticals, Inc., requested that the article be Open Choice to make the article an open access publication. Postpublication open access was funded by Alexion Pharmaceuticals, Inc. The article is forthwith distributed under the terms of the Creative Commons Attribution-NonCommercial 4.0 International License (https://creativecommons.org/ licenses/by-nc/4.0/), which permits any noncommercial use, duplication, adaptation, distribution and reproduction in any medium or format, as long as you give appropriate credit original author(s) and the source, provide a link to the Creative Commons licence and indicate if changes were made.

The original article has been corrected.

Open Access This article is licensed under a Creative Commons Attribution-NonCommercial 4.0 International License, which permits any non-commercial use, sharing, adaptation, distribution and reproduction in any medium or format, as long as you give appropriate credit to the original author(s) and the source, provide a link to the Creative Commons licence, and indicate if changes were made. The images or other third party material in this article are included in the article's Creative Commons licence, unless indicated otherwise in a credit line to the material. If material is not included in the article's Creative Commons licence and your intended use is not permitted by statutory regulation or exceeds the permitted use, you will need to obtain permission directly from the copyright holder.To view a copy of this licence, visit http://creativecommons.org/licenses/by-nc/4.0/.

The original article can be found online at https://doi.org/10.1007/ s40265-020-01297-w.

James E. Frampton

demail@springer.com

1 Springer Nature, Mairangi Bay, Private Bag 65901, Auckland 0754, New Zealand 